Document downloaded from:

http://hdl.handle.net/10251/50569

This paper must be cited as:

Aleixandre-Benavent, R.; Vidal-Infer, A.; Alonso Arroyo, A.; Valderrama Zurian, JC.; Bueno Cañigral, F.; Ferrer Sapena, A. (2014). Public availability of published research data in substance abuse journals. International Journal of Drug Policy. 25(6):1143-1146. doi:10.1016/j.drugpo.2014.07.007.

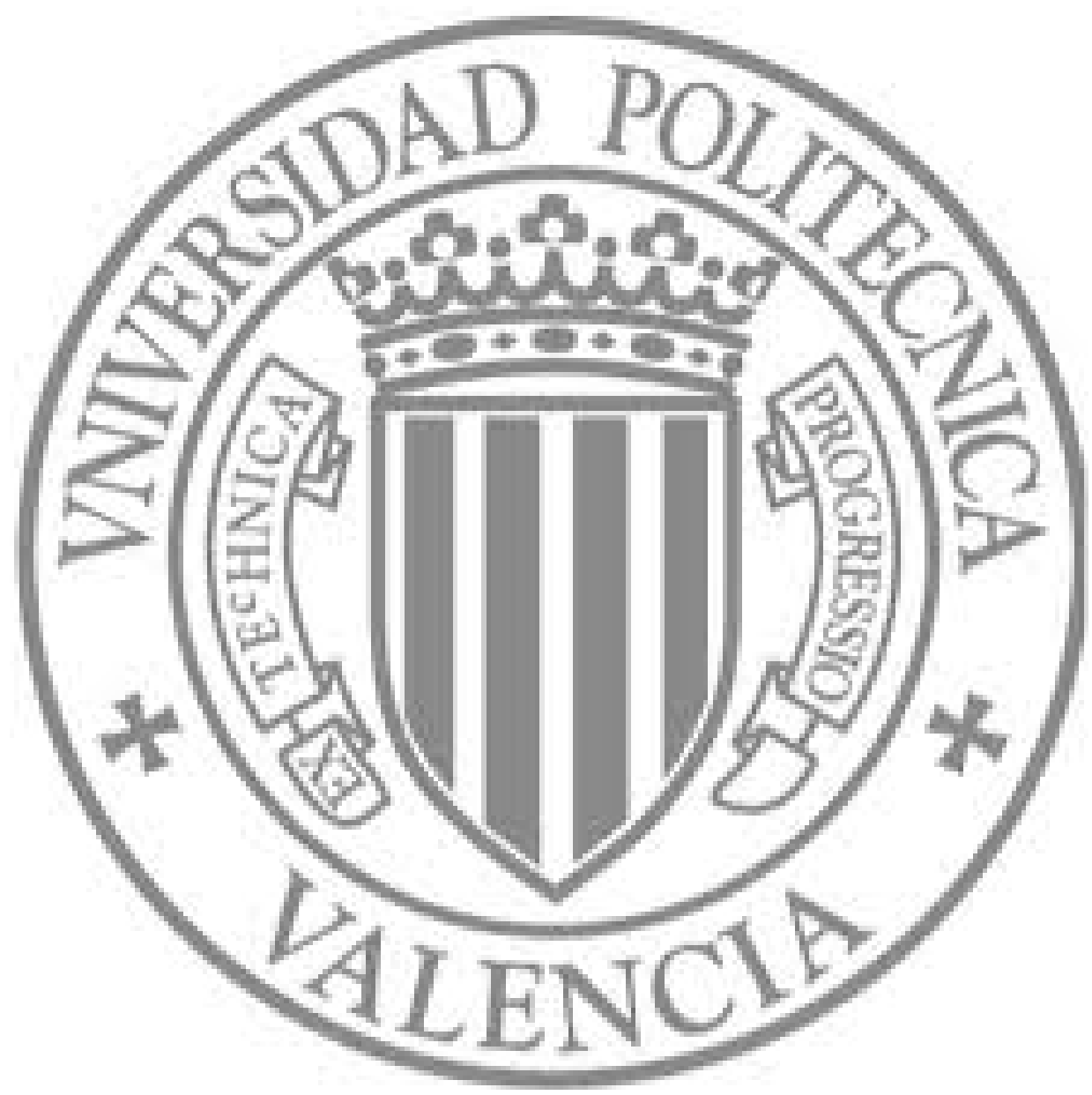

The final publication is available at

http://dx.doi.org/10.1016/j.drugpo.2014.07.007

Copyright Elsevier 


\section{PUBLIC AVAILABILITY OF PUBLISHED RESEARCH DATA IN SUBSTANCE ABUSE JOURNALS}

\section{ABSTRACT}

Sharing research data is an increasingly necessary requirement for the advancement of science. The aim of this study was to analyse the policies on openness in sharing scientific research data in substance abuse journals. Journals included in the Substance abuse area of the Journal Citation Reports were used for the analysis, with reference to the instructions to authors published on the journals' websites. In $67.6 \%$ of the journals, it is possible to store materials in thematic or institutional repositories; $47 \%$ accept supplemental material; $64.7 \%$ allow the reuse of data, and $41.2 \%$ admit the publication of their data on a website. Most journals recommend that authors deposit their data in a repository, but they do not provide clear instructions for doing so. A correlation was found between the value of a journal's impact factor and the storage and reuse. PubMed Central is the repository primarily suggested for deposit.

KEYWORDS: open research data; sharing data; substance abuse journals 


\section{BACKGROUND}

Substance abuse is an economic, political and social problem that encompasses the entire population and is experiencing a gradual normalisation in consumption. However, substance abuse remains a major public health problem globally. Data from the World Health Organization show that the harmful use of alcohol causes 2.5 million deaths each year, with $9 \%$ of the deaths occurring in individuals aged 15 to 29 years old. It is also estimated that at least 15.3 million people suffer from addictive disorders of various types, and one in twenty adults consumed illegal substances at least once during 2010. However, the resources devoted to treatment are not sufficient to address the problem because they are intended for only 1.7 beds per 100,000 inhabitants and only $30 \%$ of countries have effective medication [1].

In this situation, access to all information on all aspects of the problem takes on an importance for professionals working or researching in this field. Within the traditional system of publishing research data, only a small fraction of the data is available to the public, and in addition, the selection of these data depends on the value that the authors give to the published article [2-4].

Today, funding agencies and many researchers agree that raw data on which the research is based should be disseminated freely for future use. Therefore, scientists are increasingly encouraged to offer their data for public access, regardless of whether these data are associated with a publication. One such institution, the Royal Society, insists in its report entitled "Science as an open enterprise report" on the urgent need to provide 
public access to data, which means that they are easily locatable, interpretable, reusable and citable [5].

Scientific journals are the current system of research publication and play an important role in this process because current technology allows for the deposit of data and supplementary materials accompanying the published work [6]. However, the rules on the publication of raw data in substance related disorder journals are largely unknown. The aim of the current study is to analyse the open-data policies of the scientific research journals listed in the Substance abuse area of the Journal Citation Reports.

\section{METHODS}

We reviewed the websites of the 34 journals included in the Substance abuse category of the Journal Citation Reports (Science and Social Science editions), referring specifically to the instructions to authors. For each journal, we documented the policies related to public availability of data sharing, where available.

The following data were collected for each journal: a) Journal name; b) Publisher; c) Journal website; d) Storage in thematic or institutional repositories, including the following variables: A: Accepted, when the supplementary material can be deposited in institutional or thematic repositories and also when deposit in public repositories is required for publication in the journal; NA: Not Accepted, when explicit deposit in any repository is not allowed; NS: Not Specified, when there is no clear information on 
deposit in a repository; e) Statement of policy regarding complementary material (A; NA; NS); f) Reuse policy (A; NA; NS); and g) Policy regarding data publication on the official website or by the author (N; NA; NS). This information was collected from July 2013 to September 2013.

\section{RESULTS}

Table 1 presents the results obtained in accordance with the four main variables analysed. In relation to the variable "Storage in thematic or institutional repositories", $67.6 \%$ of the journals specified that it was possible, whereas $32.4 \%$ did not specify such a possibility. The percentage was higher for journals included in the first quartile by an impact factor in the JCR substance abuse area, but the percentage of journals that did not specify this information was higher in the fourth quartile journals. That option was not denied by any journal.

\section{TABLE 1 ABOUT HERE}

The variable "Statement of complementary material" was accepted in $47 \%$ of the journals, whereas $53 \%$ did not specify a preference. The results were quite similar in all of the quartiles.

The following results were obtained regarding the reuse of data: $64.7 \%$ of the journals support this possibility and the remaining $35.3 \%$ did not specify. The highest percentage 
of response across this variable was in the journals of the first quartile that accept the reuse of data.

The variable regarding the possibility of publishing data on a website presented the following results: $41.2 \%$ of the journals accepted it, $38.2 \%$ did not specify a policy on this option and $20.6 \%$ did not allow it.

The 43 journals included in the study are published by 18 different publishing companies or institutions (Table 2), of which 12 (35.3\%) publish only one journal. The institution that publishes the most substance abuse journals is Informa Healthcare $(n=6)$, followed by Routledge Journals, Taylor \& Francis Ltd (n=5) and Wiley-Blackwell $(n=5)$. Within each publishing entity, the policies on depositing data in repositories are variable. In four publishing entities that publish eight journals (23.5\%), PubMed Central is specified as the repository. In eight publishing entities that publish 14 journals (41.2\%), no repository was advised. In one journal, the recommended repositories were related to clinical trial registries, including Australian New Zealand Clinical Trials Registry, Clinical Trials, ISRCTN Register, Netherlands Trial Register, and UMIN Clinical Trial Register. Finally, three indicated the possibility to deposit data into repositories, but without specifying any locations. Biomed Central LTD, with two journals, is considered an open access repository.

\section{TABLE 2 ABOUT HERE}

\section{DISCUSSION}


This paper analyses open-data policies for 34 journals listed in the Substance abuse area of Journal Citation Reports and has allowed for the identification of some characteristics concerning these policies.

There are several advantages of data sharing for both researchers depositing data and researchers who reuse these data. Data sharing increases transparency in the presentation of research results and data because researchers can reproduce the experiments and test hypotheses [7]. It helps to avoid duplication of projects with similar objectives. Data sharing also generates opportunities for additional publications through collaboration [8]. The original researcher who deposited data can also benefit from new data added and placed by other researchers, while data sharing enables collaboration with other researchers attracted by the availability of shared data [3], further studies and meta-analyses [9]. Health care organisations that adopt the goals of data sharing are more attractive to advanced researchers and therefore more able to recruit the talent needed for future success, which will result in increasing excellence [10]. It has been said that data sharing increases visibility and relevance of the work and the number of citations received in later papers [11]. Data sharing is particularly important in substance abuse research because underutilising or not utilising all of the available data can lead to the unnecessary exposure of individuals participating in clinical trials for which data already exist $[12,13]$. Although most of the published studies on this topic speak in favour of the benefits of sharing, some disagree with this direction, arguing the fear of misuse of data, loss of intellectual property and confidentiality issues [14]. Some researchers also argue that exchanging data introduces 
an additional risk to subjects because the danger of losing the protection of privacy is greater once the data have been shared. Researchers who reuse the data may not maintain the same zeal in protecting the subjects as the original investigators, although they are bound by science to this legal and ethical responsibility $[3,9,14]$.

Scientific institutions increasingly show a greater interest in data sharing. The U.S. Government, through the Substance Abuse and Mental Health Services Administration (SAMHSA), provides the Substance Abuse and Mental Health Data Archive portal (SAMHDA), whose National Addiction \& HIV Data Archive Program (NAHDAP) has the aim to facilitate research on drug addiction and HIV infection by acquiring, enhancing, preserving, and sharing data produced by research grants, particularly those funded by the National Institute on Drug Abuse (NIDA) [15]. NAHDAP supports secondary data analysis through technical assistance and specialised training for data depositors and data users in the drug addiction and HIV research and policy communities. NAHDAP provides services to assist data depositors (technical assistance with data preparation, enhancing secondary use; educational activities to promote data sharing; proposal preparation and data sharing plans; and confidentiality reviews of data), Data User Services (online analysis of selected data through online Survey Documentation and Analysis; assistance with retrieval and use of data files from NAHDAP; bibliographic citations to publications based on research data in NAHDAP) and Education and Training Services (workshops; webinars on data preparation and legal and technical issues associated with data sharing; conference short courses on data management plans and data sharing; on-site technical training for depositors and research work groups to enhance data preparation). The European Monitoring Centre for Drugs and Drug Addiction (EMCDDA), which is the reference point on drugs and 
drug addiction information in Europe, also has a reusing data policy. The information provided by EMCDDA may be freely reused and reproduced accurately, but not presented in a misleading way, and all sources must be acknowledged [16].

As seen, the most recommended repository for data deposit and sometimes the only one mentioned is PubMed Central, the digital repository of biomedical literature operated by the National Library of Medicine. An example of the current importance of this repository is the number of items included on drug dependence. With the Medical Subject Heading (MeSH) "Substance-Related Disorders", we recovered 20,887 items in January 2014. Applying the limit "Articles with Supplementary Material", 1,219 items were obtained. Though this value represents only $5.8 \%$ of the total, the growth has been very strong in recent years, rising from 131 in $2008(10.7 \%)$ to 313 in $2012(25.7 \%)$. Following the example of PubMed Central, it is necessary to create institutional and subject repositories of data that allow researchers to deposit their data there, with appropriate counselling and the necessary guarantees of safeguard.

One of the limitations of this study is that it analyses only substance abuse journals included in the JCR and it is possible that different policies exist regarding other journals. However, these journals were chosen because they have a great diffusion through the WOS as well as international impact. The data obtained can thus serve as a reference for subsequent studies.

\section{Conclusions}


Most of the journals support the possibility of data storage in thematic or institutional repositories. Journals accept additional material and reuse of data, but most of them have no specific instructions for authors to follow and present uncertainty as to the possibility of publishing the data on a website. There is no relationship between openness policies and the impact of the journals according to their quartile or position ranking by impact factor in the JCR. Deposit policies vary among publishing entities, with PubMed Central and repositories of clinical trials among those predominantly suggested for data deposit. The dispersed and multidisciplinary nature of international research networks on drug addiction is an argument in favour of open-data by allowing reuse by multiple researchers for a variety of purposes. Future work along these lines could analyse policies in other journals not included in WOS as well as the practices and perceptions of specialists in substance abuse regarding data accessibility, reuse, preservation and data sharing in an effort to identify barriers to effective data sharing.

\section{Acknowledgment}

This work has benefited from assistance by the National $\mathrm{R}+\mathrm{D}+\mathrm{I}$ of the Ministry of Economy and Competitiveness of the Spanish Government, the Mapfre Foundation and Plan Municipal de Drogodependencias from Valencia municipality, Spain. 


\section{REFERENCES}

1. WHO, 2013. Accessed: 21/10/2013. Available from http://www.who.int/substance_abuse/facts/en/index.html.

2. Leonelli S, Smirnoff N, Moore J, Cook C. Making open data work for plant scientists. J Exp Bot. 2013; 1-9. doi:10.1093/jxb/ert273

3. Guttmacher AE, Nabel EG, Collins FS. Why data-sharing policies matter. ProcNatlAcadSci U S A. 2009 Oct 6;106(40):16894. doi: 10.1073/pnas.0910378106. Epub 2009 Sep 18.

4. Murray-Rust, Peter. Open Data in Science. Available from Nature Precedings $<$ http://hdl.handle.net/10101/npre.2008.1526.1> (2008).

5. The Royal Society. Science as an opne Enterprise. Accessed: 21/10/2013. Available from http://royalsociety.org/policy/projects/science-public-enterprise/report/

6. Tenopir C, Allard S, Douglass K, Aydinoglu AU, Wu L, Read E, Manoff M, Frame M. Data sharing by scientists: practices and perceptions. PLoS One. 2011;6(6):e21101.

7. Rennolls, Keith. “Science demands data sharing”. BMJ 1997;315 (7106): 486.

8. Piwowar HA, Todd J. Data reuse and the open data citation advantage Vision Peer J. 2013; 1: e175. 
9. Aleixandre-Benavent R, Ferrer-Sapena A, Alonso-Arroyo A, Peset F. Compartir datos de investigación en Cardiología. Sharing research data in Cardiology. Rev Esp Cardiol. 2013; 66:1007-8.

10. Butler D, 2007. Data sharing threatens privacy. Nature 449, 644-645 (2007)

11. Piwowar HA, Day RS, Fridsma DB. Sharing Detailed Research Data Is Associated with Increased Citation Rate PLoS ONE. 2007; 2(3): e308.

12. Vickers AJ. Whose data set is it anyway? Sharing raw data from randomized trials. Trials. 2006;16:7:15.

13. Pisani E, AbouZahr C. Sharing health data: good intentions are not enough.Bull World Health Organ. 2010 Jun;88(6):462-6. doi: 10.2471/BLT.09.074393.

14. Kaye $\mathrm{J}$. The tension between data sharing and the protection of privacy ingenomics research.Annu Rev Genomics Hum Genet. 2012;13:415-31. doi:10.1146/annurevgenom-082410-101454. Epub 2012 Mar 9. Review. PubMed PMID:22404490.

15. González LM, Saorín T, Ferrer A, Aleixandre-Benavent R, Peset F. Gestión de datos de investigación: infraestructuras para su difusión. Prof Inf. 2013;22:414-23.

16. Substance Abuse and Mental Health Data Archive (SAMHDA). Accessed 7 January 2014. Available from https://www.icpsr.umich.edu/icpsrweb/SAMHDA/

17. European Monitoring Centre for Drugs and Drug Addiction (EMCDDA). Accessed 7 January 2014. Available from http://www.emcdda.europa.eu/ 
Table 1. Results from main variables analyzed

\begin{tabular}{|l|l|l|l|l|l|l|l|l|l|l|l|l|}
\hline \multirow{2}{*}{$\begin{array}{l}\text { Q } \\
*\end{array}$} & $\begin{array}{l}\text { Storage in thematic or } \\
\text { institutional repositories }\end{array}$ & \multicolumn{2}{l|}{$\begin{array}{l}\text { Statement of } \\
\text { complementary material }\end{array}$} & \multicolumn{2}{l|}{ Reuse } & \multicolumn{2}{l|}{ Publication in website } \\
\cline { 2 - 12 } & A & NA & NS & A & NA & NS & A & NA & NS & A & NA & NS \\
\hline & $\begin{array}{l}\text { N } \\
(\%)\end{array}$ & $\begin{array}{l}\text { N } \\
(\%)\end{array}$ & $\begin{array}{l}\text { N } \\
(\%)\end{array}$ & $\begin{array}{l}\text { N } \\
(\%)\end{array}$ & $\begin{array}{l}\text { N } \\
(\%)\end{array}$ & $\begin{array}{l}\text { N } \\
(\%)\end{array}$ & $\begin{array}{l}\text { N } \\
(\%)\end{array}$ & $\begin{array}{l}\text { N } \\
(\%)\end{array}$ & $\begin{array}{l}\text { N } \\
(\%)\end{array}$ & $\begin{array}{l}\text { N } \\
(\%)\end{array}$ & $\begin{array}{l}\text { N } \\
(\%)\end{array}$ & $\begin{array}{l}\text { N } \\
(\%)\end{array}$ \\
\hline 1 & 8 & - & 1 & 4 & - & 5 & 8 & - & 1 & 3 & 1 & 5 \\
& $88,8 \%$ & & $11,2 \%$ & $44,4 \%$ & & $55,6 \%$ & $88,8 \%$ & & $11,2 \%$ & $33,3 \%$ & $11,1 \%$ & $55,6 \%$ \\
\hline 2 & 6 & - & 2 & 4 & - & 4 & 6 & - & 2 & 3 & 1 & 4 \\
& $75 \%$ & & $25 \%$ & $50 \%$ & & $50 \%$ & $75 \%$ & & $25 \%$ & $37,5 \%$ & $12,5 \%$ & $50 \%$ \\
\hline 3 & 6 & - & 3 & 4 & - & 5 & 5 & - & 4 & 7 & 2 & - \\
& $66,7 \%$ & & $33,3 \%$ & $44,4 \%$ & & $55,6 \%$ & $55,6 \%$ & & $44,4 \%$ & $77,8 \%$ & $22,2 \%$ & \\
\hline 4 & 3 & - & 5 & 4 & - & 4 & 3 & - & 5 & 1 & 3 & 4 \\
& $37,5 \%$ & & $62,5 \%$ & $50 \%$ & & $50 \%$ & $37,5 \%$ & & $62,5 \%$ & $12,5 \%$ & $37,5 \%$ & $50 \%$ \\
\hline
\end{tabular}

* Q: Quartil in Substance Abuse category in Journal Citation Reports SCI and SSCI. In case of simultaneous presence in both editions the highest Rank was selected.

(A: Accepted; NA: Not Accepted; NS: Not Specified) 
Table 2. Recommended repositories from publishers

\begin{tabular}{|c|c|c|c|}
\hline Publishers & $\begin{array}{c}\mathrm{N}^{\mathrm{o}} \\
\text { journals }\end{array}$ & Journals & Recommended repositories \\
\hline $\begin{array}{l}\text { Alcohol Res } \\
\text { Documentation Inc } \\
\text { Cent Alcohol Stud } \\
\text { Rutgers Univ }\end{array}$ & 1 & $\begin{array}{l}\text { - Journal of Studies } \\
\text { on Alcohol and } \\
\text { Drugs }\end{array}$ & PubMed Central \\
\hline Baywood Publ Co Inc & 1 & $\begin{array}{l}\text { - Journal of Drug } \\
\text { Education }\end{array}$ & $\begin{array}{l}\text { Do not recommend any } \\
\text { repository }\end{array}$ \\
\hline Biomed Central Ltd & 2 & $\begin{array}{l}\text { - Harm Reduction } \\
\text { Journal } \\
\text { - Substance Abuse } \\
\text { Treatment, } \\
\text { Prevention, and } \\
\text { Policy }\end{array}$ & $\begin{array}{l}\text { It's an open access } \\
\text { repository }\end{array}$ \\
\hline $\begin{array}{l}\text { Educational Publishing } \\
\text { Foundation-American } \\
\text { Psychological } \\
\text { Association }\end{array}$ & 1 & $\begin{array}{l}\text { - Psychology of } \\
\text { Addictive } \\
\text { Behaviors }\end{array}$ & $\begin{array}{l}\text { Depending on the deposit } \\
\text { requirements of your } \\
\text { research funding agency, } \\
\text { the APA will deposit either } \\
\text { the accepted peer-reviewed } \\
\text { manuscript or the final }\end{array}$ \\
\hline Elsevier Ireland Ltd & 1 & $\begin{array}{l}\text { - Drug and Alcohol } \\
\text { Dependence }\end{array}$ & $\begin{array}{l}\text { Australian New Zealand } \\
\text { Clinical Trials Registry; } \\
\text { Clinical Trials; ISRCTN } \\
\text { Register; Netherlands Trial } \\
\text { Register; UMIN Clinical } \\
\text { Trials Registry }\end{array}$ \\
\hline Elsevier Science & 2 & $\begin{array}{l}\text { - International } \\
\text { Journal of Drug } \\
\text { Policy } \\
\text { - Alcohol }\end{array}$ & $\begin{array}{l}\text { Do not recommend any } \\
\text { repository }\end{array}$ \\
\hline Informa Healthcare & 6 & $\begin{array}{l}\text { - American Journal } \\
\text { on Drug and } \\
\text { Alcohol Abuse } \\
\text { - Substance Use \& } \\
\text { Misuse } \\
\text { - Addiction } \\
\text { Research \& } \\
\text { Theory } \\
\text { - Journal of } \\
\text { Addictions } \\
\text { Nursing } \\
\text { - Drugs: Education, } \\
\text { Prevention, and } \\
\text { Policy } \\
\text { - Journal of } \\
\text { Substance Use }\end{array}$ & $\begin{array}{l}\text { Informa Healthcare } \\
\text { requests, as a consideration } \\
\text { of publication, that clinical } \\
\text { trials are registered in a } \\
\text { public repository at their } \\
\text { inception and prior to } \\
\text { patient }\end{array}$ \\
\hline $\begin{array}{l}\text { Journal of Drug Issues } \\
\text { Inc }\end{array}$ & 1 & $\begin{array}{l}\text { - Journal of Drug } \\
\text { Issues }\end{array}$ & $\begin{array}{l}\text { Do not recommend any } \\
\text { repository }\end{array}$ \\
\hline Karger & 1 & - European & PubMed Central \\
\hline
\end{tabular}




\begin{tabular}{|c|c|c|c|}
\hline & & $\begin{array}{l}\text { Addiction } \\
\text { Research }\end{array}$ & \\
\hline $\begin{array}{l}\text { Lippincott Williams \& } \\
\text { Wilkins }\end{array}$ & 1 & $\begin{array}{l}\text { - Journal of } \\
\text { Addiction } \\
\text { Medicine }\end{array}$ & PubMed Central \\
\hline $\begin{array}{l}\text { Natl Inst Alcohol } \\
\text { Abuse Alcoholism }\end{array}$ & 1 & $\begin{array}{l}\text { - Alcohol Research } \\
\text { \& Health }\end{array}$ & $\begin{array}{l}\text { Do not recommend any } \\
\text { repository }\end{array}$ \\
\hline Oxford Univ Press & 1 & $\begin{array}{l}\text { - Alcohol \& } \\
\text { Alcoholism } \\
\end{array}$ & $\begin{array}{l}\text { Institutional and/or centrally } \\
\text { organized repositories }\end{array}$ \\
\hline Pacini Editore & 1 & $\begin{array}{l}\text { - Heroin addiction } \\
\text { and related clinical } \\
\text { problems }\end{array}$ & $\begin{array}{l}\text { Do not recommend any } \\
\text { repository }\end{array}$ \\
\hline $\begin{array}{l}\text { Pergamon-Elsevier } \\
\text { Science ltd }\end{array}$ & 2 & $\begin{array}{l}\text { - Journal of } \\
\text { Substance Abuse } \\
\text { Treatment } \\
\text { - Addictive } \\
\text { Behaviors } \\
\end{array}$ & $\begin{array}{l}\text { Do not recommend any } \\
\text { repository }\end{array}$ \\
\hline $\begin{array}{l}\text { Routledge Journals, } \\
\text { Taylor \& Francis ltd }\end{array}$ & 5 & $\begin{array}{l}\text { - Journal of } \\
\text { Addictive } \\
\text { Diseases } \\
\text { - Substance Abuse } \\
\text { - Journal of } \\
\text { Psychoactive } \\
\text { Drugs } \\
\text { - Journal of Dual } \\
\text { Diagnosis } \\
\text { - Journal of Child \& } \\
\text { Adolescent } \\
\text { Substance Abuse } \\
\end{array}$ & $\begin{array}{l}\text { Do not recommend any } \\
\text { repository }\end{array}$ \\
\hline Socidrogalcohol & 1 & - Adicciones & $\begin{array}{l}\text { Do not recommend any } \\
\text { repository }\end{array}$ \\
\hline Springer & 1 & $\begin{array}{l}\text { - Journal of } \\
\text { Gambling Studies }\end{array}$ & Open access repositories \\
\hline Wiley-Blackwell & 5 & $\begin{array}{l}\text { - Addiction Biology } \\
\text { - Addiction } \\
\text { - Alcoholism: } \\
\text { Clinical and } \\
\text { Experimental } \\
\text { Research } \\
\text { - The American } \\
\text { Journal on } \\
\text { Addictions } \\
\text { - Drug and Alcohol } \\
\text { Review } \\
\end{array}$ & PubMed Central \\
\hline
\end{tabular}




\section{Statement 1: Role of Funding Sources}

This work has benefited from assistance by the National $\mathrm{R}+\mathrm{D}+\mathrm{I}$ of the Ministry of Economy and Competitiveness of the Spanish Government, the Mapfre Foundation and Plan Municipal de Drogodependencias from Valencia municipality, Spain.

\section{Statement 2: Contributors}

JCV and FBC have developed the journals' website analysis. AFS and AAA have conducted the data analysis. RAB and AVI have coordinated the work. All the authors have materially participated in the design of the research and/or the manuscript preparation and they have approved the final manuscript.

\section{Statement 3: Conflict of Interest}

There are no conflicts of interest by any author 